\title{
Structural Behavior of Tall Building Raft Foundations in Earthquake Zones
}

\author{
Mohammed S. Al-Ansari \\ Civil Engineering Department, Qatar University, Doha, Qatar \\ Email: m.alansari@qu.edu.qa
}

How to cite this paper: Al-Ansari, M.S. (2017) Structural Behavior of Tall Building Raft Foundations in Earthquake Zones. Open Journal of Earthquake Research, 6, 180-190. https://doi.org/10.4236/ojer.2017.64011

Received: August 15, 2017

Accepted: October 13, 2017

Published: October 16, 2017

Copyright $\odot 2017$ by author and Scientific Research Publishing Inc. This work is licensed under the Creative Commons Attribution International License (CC BY 4.0).

http://creativecommons.org/licenses/by/4.0/

\begin{abstract}
The paper studies the behavior of reinforced concrete raft foundations for multi-story buildings. It also develops a reliability assessment tool for multi-story building raft foundations subjected to earthquake loading. Several multi-story buildings with various configurations, heights, and soil profiles, were subjected to several ACI code combinations of gravity and earthquake loads from different seismic zones. The reliability of the raft foundations of these buildings was assessed using the reliability index approach based on their resistance to the applied loads. Also, the responses of the multi-story buildings under these loading combinations were studied and analyzed in order to draw recommendations and guidelines for the preliminary design of structurally efficient and reliable raft foundations in earthquake zones.
\end{abstract}

\section{Keywords}

Raft Foundation, Earthquake Loads, Foundation Settlements, Building Drift, Reliability Index, Structural and Soil Parameters

\section{Introduction}

Most multi-story buildings use raft foundations as structural elements to resist applied loads and transfer safely to the soil. The reliability and response of raft foundations were studied using the reliability index $\beta$ and finite element analysis, respectively [1] [2]. The reliability index $\beta$ measures the reliability level of raft foundations based on their response to applied loads and according to their design codes. The reliability index chart is very useful for determining the raft foundation strength capacity for a desired level of reliability [3]. 3D finite element models were developed for multi-story building raft foundations to analyze their safety, stability, deformation, and crack formation based on the ACI code [4] [5] [6] [7]. First, the commercial finite element software, STAAD-Pro, was 
used to analyze and design several reinforced concrete buildings with various configurations, heights, earthquake zones, and soil profiles and subjected to ACI combinations of gravity and earthquake loads. STAAD-Pro was also used to determine the building support reactions. Then, the finite element software (Staad-Foundation) was used to design the raft foundations using the building support reactions as point loads to achieve an efficient design that satisfies all ACI requirements [8].

This paper studies the behavior of reinforced concrete raft foundations for multi-story buildings. It also develops a reliability assessment tool for raft foundations in multi-story buildings that are subjected to earthquake loading. The reliability of raft foundations was also assessed using the reliability index approach.

\section{Reliability Formulation}

A raft foundation fails when its resistance is less than the action caused by the applied loads. The raft foundation resistance and action are computed using the design strength $M_{c}$ and the external bending moment $M_{e}$, respectively. Raft foundations fail when the resistance of the raft is less than the action caused by the applied load. The raft resistance is measured using the design moment strength $M_{c}$ while the raft action is measured by the external bending moments $M_{e}$ as shown in Figure 1.

The raft limit state function is given by the following equation:

$$
G\left(A_{s}, f_{c}^{\prime}, f_{y}, M_{e}\right)=M_{c}-M_{e}
$$

where: $M_{c}=$ design bending strength, $M_{e}=$ external bending moment $\left(M_{y}^{-} ; M_{x}^{-} ; M_{y}^{+} ; M_{x}^{+}\right), A_{s}=$ tensile steel area $\left(A S_{y}^{-} ; A S_{x}^{-} ; A S_{y}^{+} ; A S_{y}^{+}\right) ; f_{y}=$ reinforcing steel yield strength, and $f_{c}^{\prime}=$ concrete compressive strength.

The raft limit state function is given by the following equation:

$$
G\left(A_{s}, f_{c}^{\prime}, f_{y}, M_{e}\right)=\phi \mu_{A s} \mu_{f y}\left(d-\frac{1}{2} \frac{\mu_{A S} \mu_{f y}}{0.85 f_{c}^{\prime} \mu_{f_{c}^{\prime}}}\right)-\mu_{M e}
$$

where: $\phi=$ bending strength reduction factor, $\mu_{f y}=$ mean value of $f_{\dot{y} \dot{ }} \quad \mu_{f_{c}^{\prime}}=$ mean value of $f_{c}^{\prime}, \mu_{A s}=$ mean value of $A_{\mathcal{S}}$ and $\mu_{M e}=$ mean value of $M_{e^{*}}$
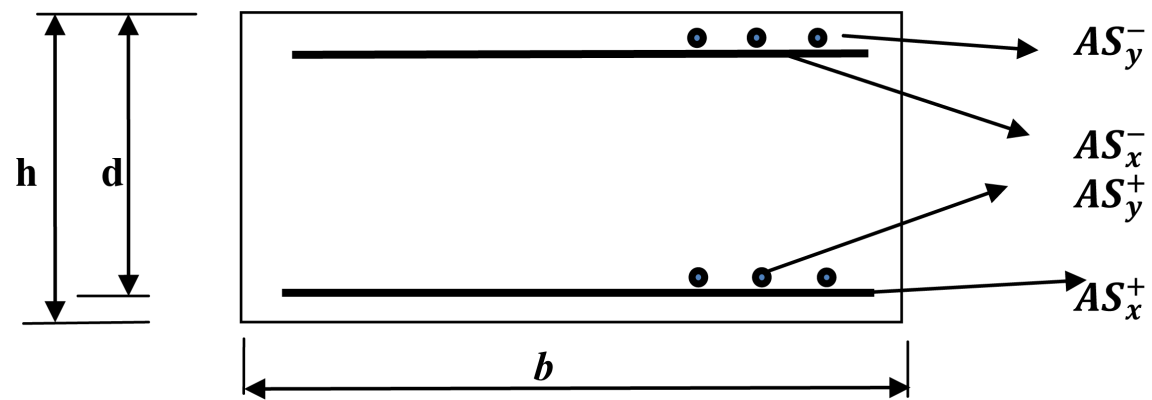

Figure 1. Rectangular reinforced concrete raft cross section. 
Because the limit state function is nonlinear, a Taylor series expansion was used to linearize it and obtain an approximate answer [9]. The Taylor expansion about the mean value yields the following equation:

$$
\begin{aligned}
G\left(A_{s}, f_{c}^{\prime}, f_{y}, M_{e}\right)= & \left(\phi \mu_{A S} \mu_{f y}\left(d-\left(\frac{1}{2}\right) \frac{\mu_{A S} \mu_{f y}}{0.85 f_{c}^{\prime} \mu_{f_{c}^{\prime}}}\right)-\mu_{M e}\right) \\
& +\left(A_{S}-\mu_{A S}\right) \frac{\mathrm{d} G}{\mathrm{~d} A_{S}}+\left(f_{y}-\mu_{f y}\right) \frac{\mathrm{d} G}{\mathrm{~d} f_{y}}+\left(f_{c}^{\prime}-\mu_{f_{c}^{\prime}}\right) \frac{\mathrm{d} G}{\mathrm{~d} f_{c}^{\prime}}
\end{aligned}
$$

The reliability index $\beta$ of the linear function is given by the following equation:

$$
\beta=\frac{G\left(A_{s}, f_{c}^{\prime}, f_{y}, M_{e}\right)}{\sqrt{\left(\sigma_{A S} a_{1}\right)^{2}+\left(\sigma_{f y} a_{2}\right)^{2}+\left(\sigma_{f_{c}^{\prime}} a_{3}\right)^{2}+\left(\sigma_{M \mathrm{e}} a_{4}\right)^{2}}}
$$

where: $\sigma_{A S}=$ standard deviation of $A S, \sigma_{f y}=$ standard deviation of $f_{y}, \sigma_{f_{c}^{\prime}}=$ standard deviation of $f_{c}^{\prime}$; and $\sigma_{M e}=$ standard deviation of $M_{e^{*}}$

The parameters $a_{1}, a_{2}, a_{3}$, and $a_{4}$ are computed using the following equations:

$$
\begin{aligned}
& a_{1}=\frac{\partial G}{\partial A S}\left(\phi A_{s} f_{y}\left(d-\left(\frac{1}{2}\right) \frac{\mu_{A S} \mu_{f y}}{0.85 f_{c}^{\prime} \mu_{f_{c}^{\prime}}}\right)-M_{e}\right) \\
& a_{2}=\frac{\partial G}{\partial f_{y}}\left(\phi A_{S} f_{y}\left(d-\left(\frac{1}{2}\right) \frac{\mu_{A S} \mu_{f y}}{0.85 f_{c}^{\prime} \mu_{f_{c}^{\prime}}}\right)-M_{e}\right) \\
& a_{3}=\frac{\partial G}{\partial f_{c}^{\prime}}\left(\phi A_{S} f_{y}\left(d-\left(\frac{1}{2}\right) \frac{\mu_{A S} \mu_{f y}}{0.85 f_{c}^{\prime} \mu_{f_{c}^{\prime}}}\right)-M_{e}\right) \\
& a_{4}=\frac{\partial G}{\partial M_{e}}\left(\phi A_{S} f_{y}\left(d-\left(\frac{1}{2}\right) \frac{\mu_{A S} \mu_{f y}}{0.85 f_{c}^{\prime} \mu_{f_{c}^{\prime}}}\right)-M_{e}\right)
\end{aligned}
$$

\begin{tabular}{|c|c|c|c|c|c|c|c|c|c|}
\hline \multirow[b]{2}{*}{$\begin{array}{c}M_{e} \\
(\mathrm{kN} \cdot \mathrm{m})\end{array}$} & \multicolumn{6}{|c|}{ Raft Slab Data } & \multirow[b]{2}{*}{$\begin{array}{c}M_{e} \\
(\mathrm{kN} \cdot \mathrm{m})\end{array}$} & \multirow[b]{2}{*}{$b$} & \multirow{2}{*}{$\begin{array}{c}\text { Safety } \\
\text { Percentage } \\
(\%)\end{array}$} \\
\hline & $\begin{array}{c}f_{c}^{\prime} \\
(\mathrm{MPa})\end{array}$ & $\begin{array}{c}f_{y} \\
(\mathrm{MPa})\end{array}$ & $\begin{array}{c}b \\
(\mathrm{~mm})\end{array}$ & $\begin{array}{c}h \\
(\mathrm{~mm})\end{array}$ & $\begin{array}{c}d \\
(\mathrm{~mm})\end{array}$ & $\begin{array}{c}A_{S} \\
\left(\mathrm{~mm}^{2}\right)\end{array}$ & & & \\
\hline 92 & \multirow{6}{*}{420} & \multirow{6}{*}{30} & \multirow{6}{*}{1000} & 300 & 240 & 1239 & 108 & 1 & 15 \\
\hline 135 & & & & 350 & 290 & 1635 & 171 & 1.5 & 21 \\
\hline 210 & & & & 500 & 440 & 2251 & 258 & 2 & 19 \\
\hline 2480 & & & & 1800 & 1740 & 4518 & 2098 & 1 & 18 \\
\hline 3320 & & & & 2000 & 1940 & 5897 & 4216 & 1.5 & 21 \\
\hline 4730 & & & & 2500 & 2044 & 7222 & 6500 & 2 & 27 \\
\hline
\end{tabular}

The standard deviation $\sigma$ is equal to the product of the mean value $\mu$ and the coefficient of variation $V$. The formulation estimates the reliability index $\beta$ of reinforced concrete raft foundations when subjected to flexural loads, based on their resistance to applied loads as shown in Table 1 and Figure 2.

Table 1. Raft reliability analysis results. 


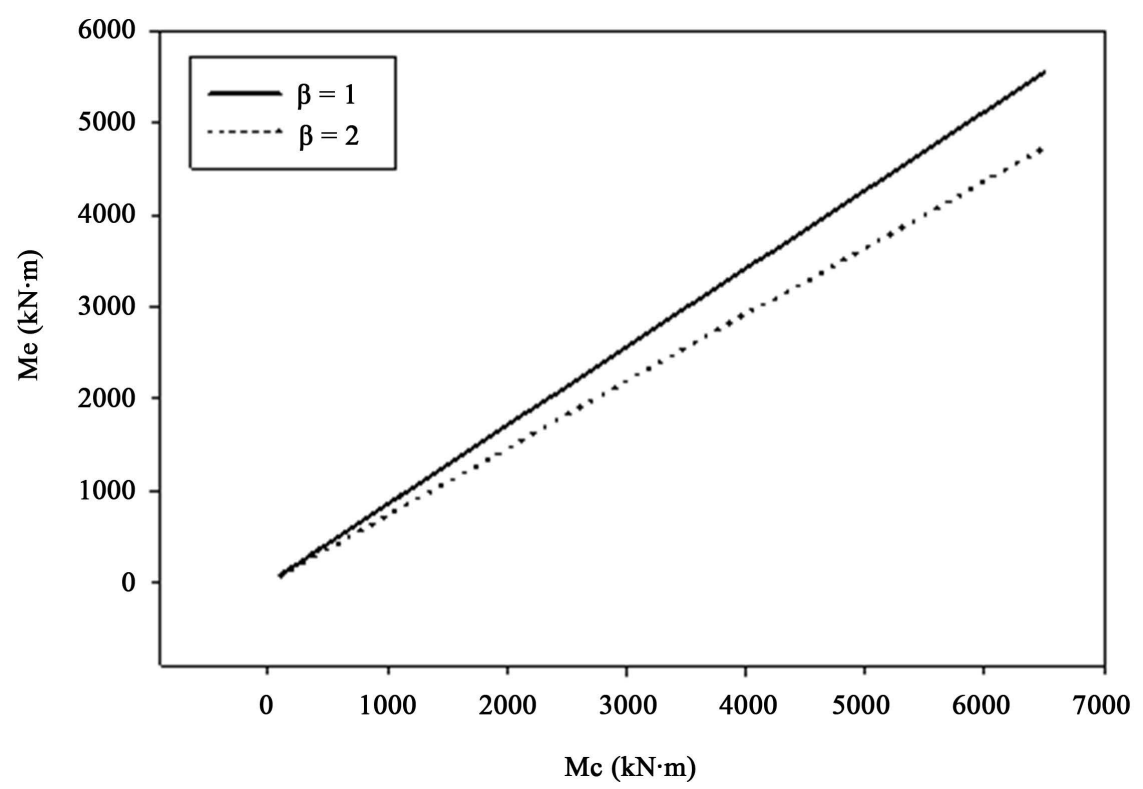

Figure 2. Raft reliability index.

\section{Finite Element Analysis}

Figure 1 shows the layout and steel detailing of a raft foundation for a high-rise building. The raft foundations are designed in earthquake zones to transmit building gravity and earthquake loads to the supporting soil without failure or large settlement $(1-4)$. The buildings considered herein had various heights and shapes (i.e., square, rectangular, tube, and circular) and included reinforced concrete shear walls (Figures 3-9). They were subjected to earthquake loads with a drift index of 0.002 [5] [6] [7] for different seismic zones and soil profiles as defined by the Uniform building Code (UBC) and the International Building Code (IBC), as shown in Table 2. The building responses and reactions were obtained using the finite element software STAAD-Pro [10].

A nonlinear finite element analysis was conducted using the commercial software STAAD-PRO to obtain the building drifts and reactions [8] [9] [11]. The buildings reactions were then used as point loads for the design of the raft foundations using STAAD-Foundation [12]. As shown in Table 3, several parameters were used in the design, namely, concrete unit weight, $\gamma_{c}$; soil density, $\gamma_{s}$; allowable soil pressure, $Q_{s}$; reinforcing steel bar yield strength, $f_{y}$; concrete compressive strength, $f_{c}^{\prime}$; and settlement $\Delta$.

\section{Results and Discussion}

Reinforced concrete raft foundations for various structural buildings models were simulated, analyzed, and optimally designed optimally as per ACI design code. Figure 10 summarizes the design procedure for raft foundations.

The square, rectangular, tube, and circular buildings were subjected to earthquake loads defined by UBC and IBC codes, for different seismic zones and soil profiles. The building support reactions were obtained using the finite element 


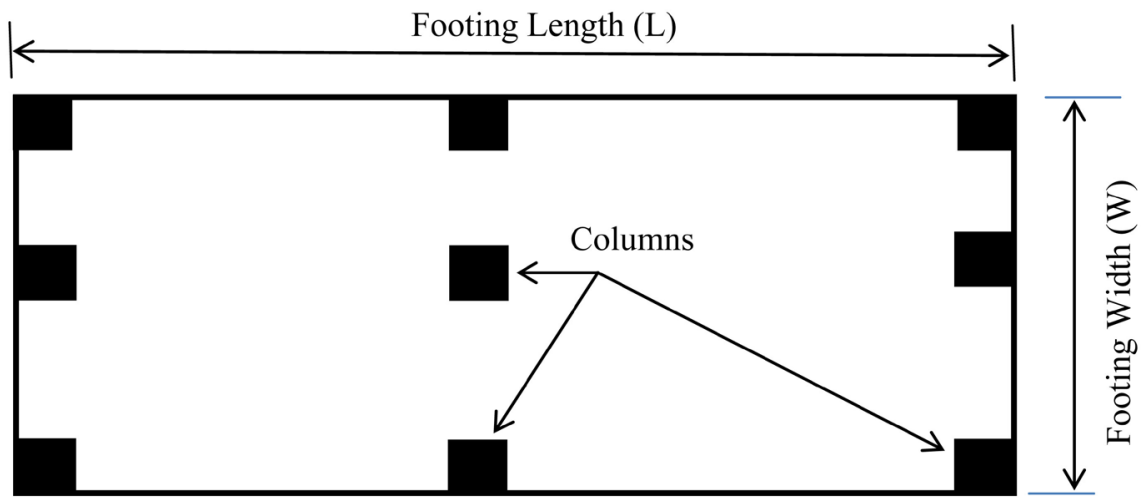

(a)

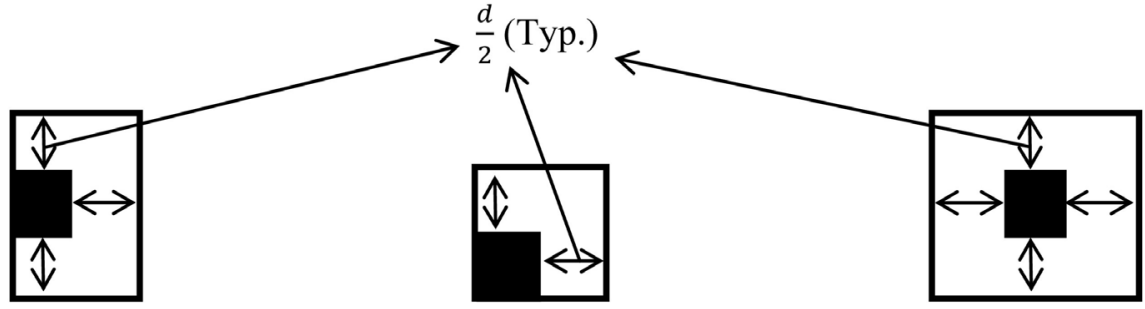

(b)

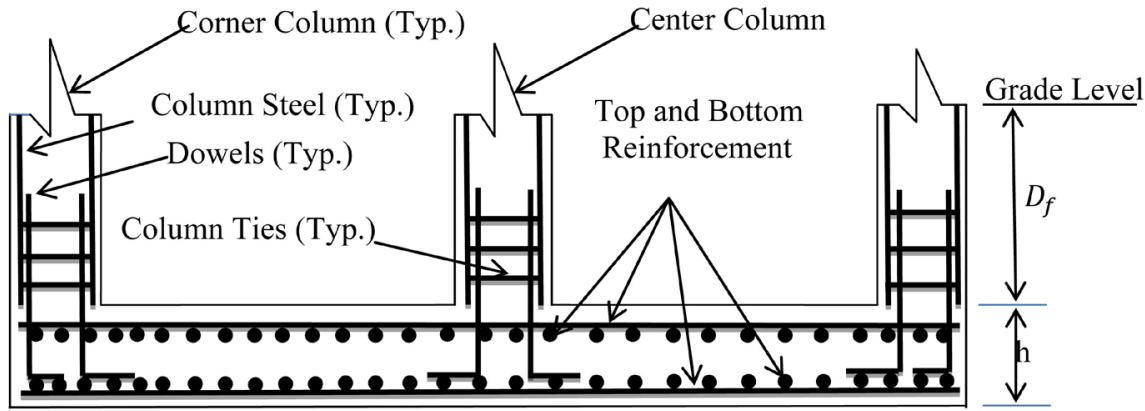

(c)

Figure 3. (a) Raft and column layout; (b) Shear critical sections; (c) Longitudinal steel reinforcement detailing.

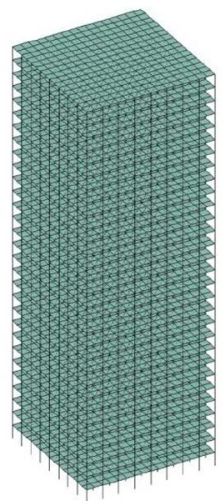

Model 1

Square-Rectangular

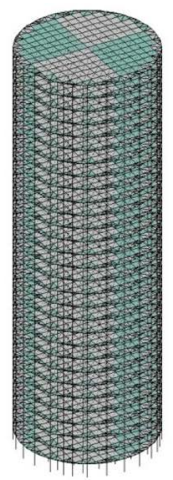

Model 2

Circular

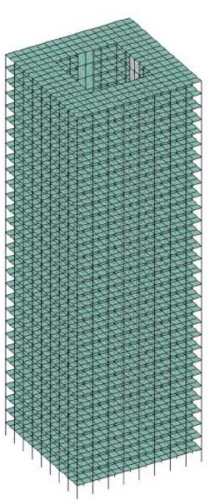

Model 3

Tube

Figure 4. 3D structural building models. 


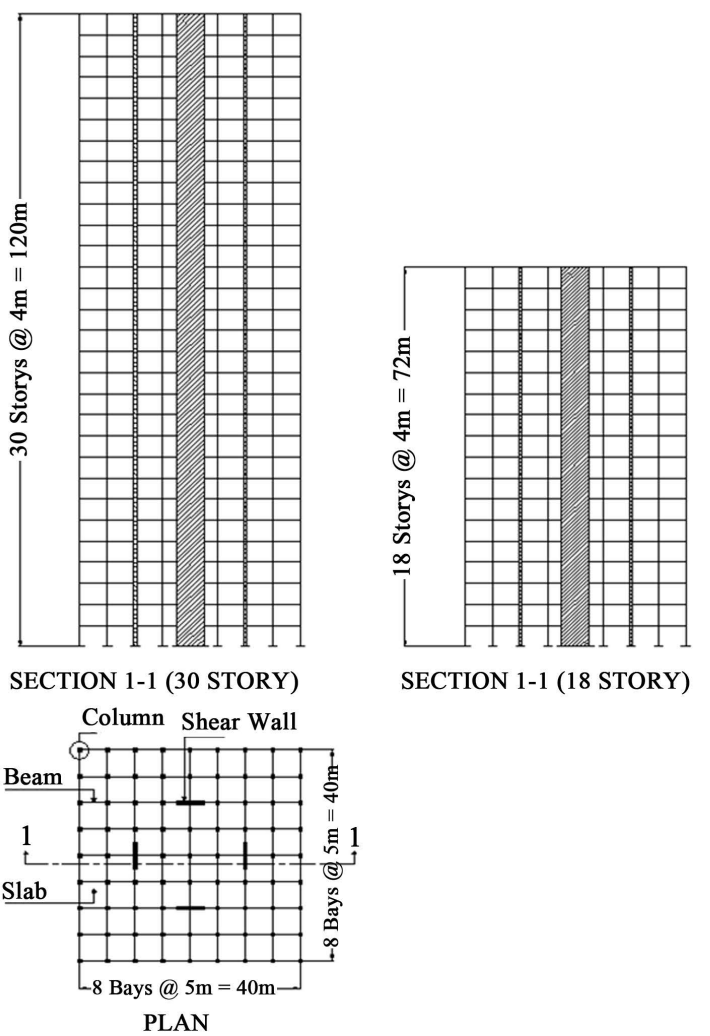

Figure 5. Square building plan and elevation.
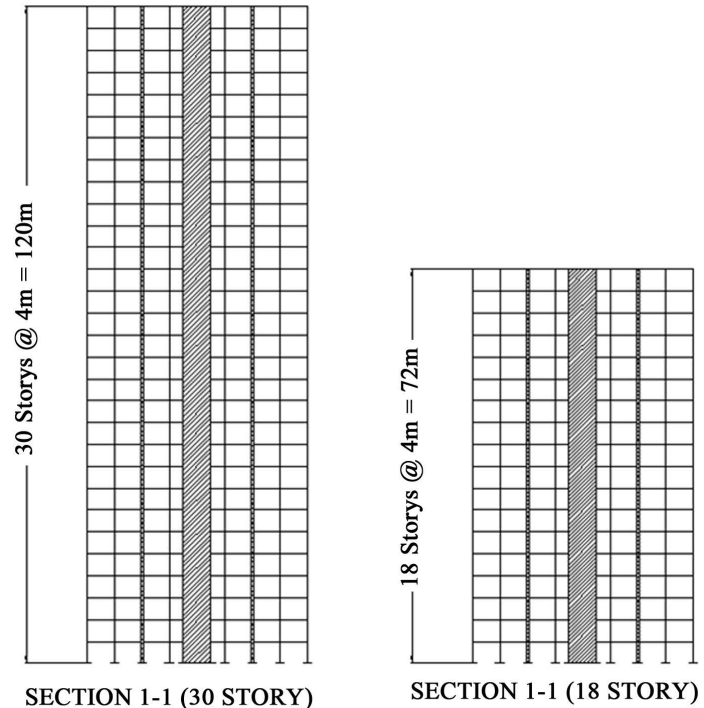

SECTION 1-1 (30 STORY)

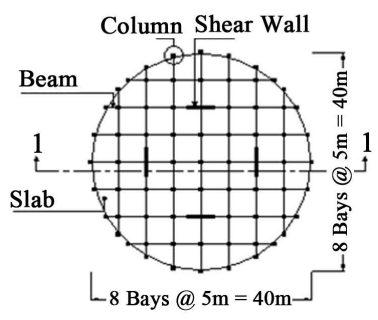

PLAN

Figure 6. Circular building plan and elevation. 


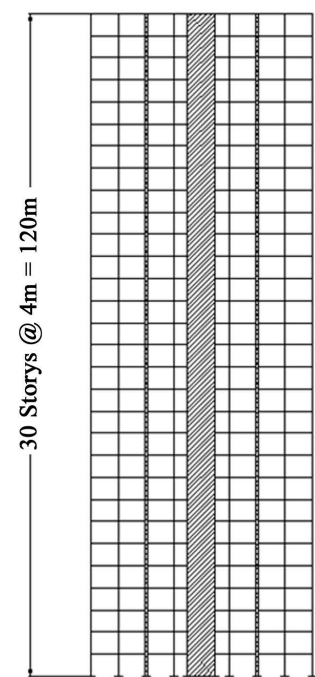

SECTION 1-1 (30 STORY)

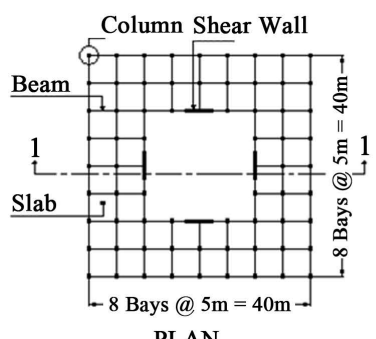

PLAN

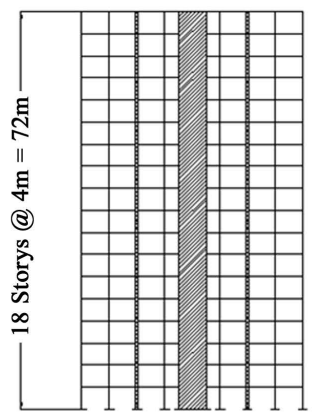

SECTION 1-1 (18 STORY)

Figure 7. Tube building plan and elevation.

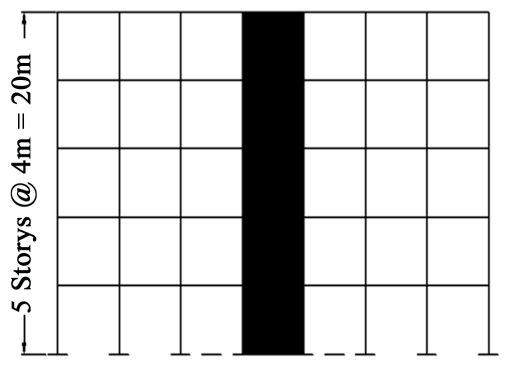

SECTION A-A

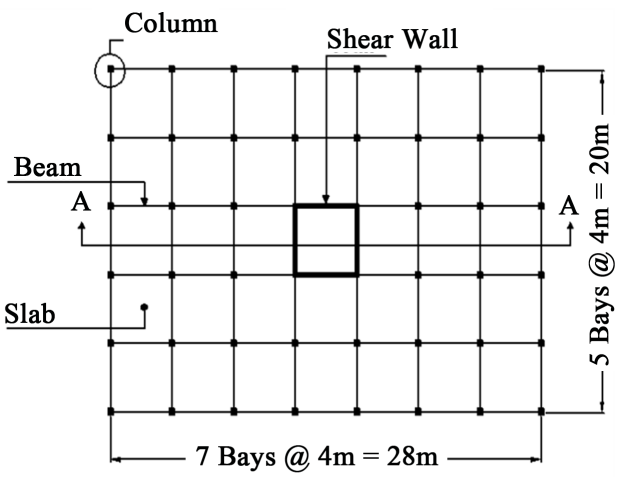

PLAN

Figure 8. Rectangular building plan and elevation.

Table 2. Soil profile and seismic factors.

\begin{tabular}{cc}
\hline Soil Type (S) & Seismic Factors (Z) \\
\hline Hard Rock (S1) & 0.075 gravitational acceleration (Z1) \\
Rock (S2) & 0.150 gravitational acceleration (Z2) \\
Very dense soil and soft rock (S3) & 0.20 gravitational acceleration (Z3) \\
Stiff soil ( S4) & 0.30 gravitational acceleration (Z4) \\
Soft soil (S5) & 0.40 gravitational acceleration (Z5)
\end{tabular}




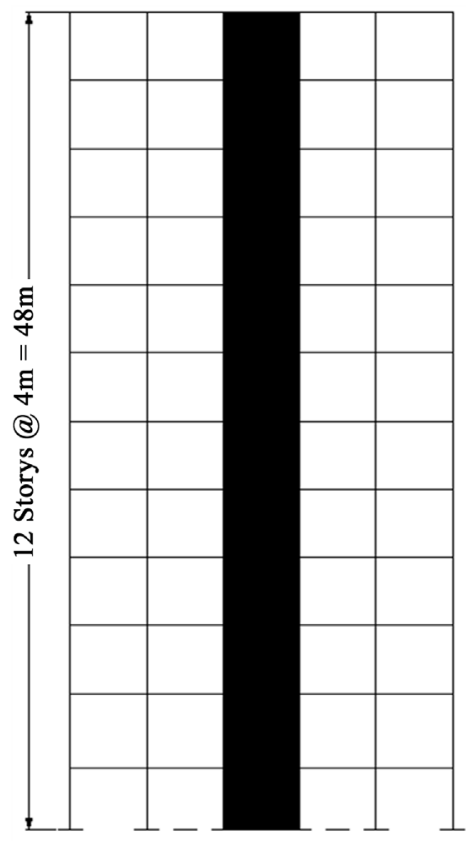

SECTION A-A

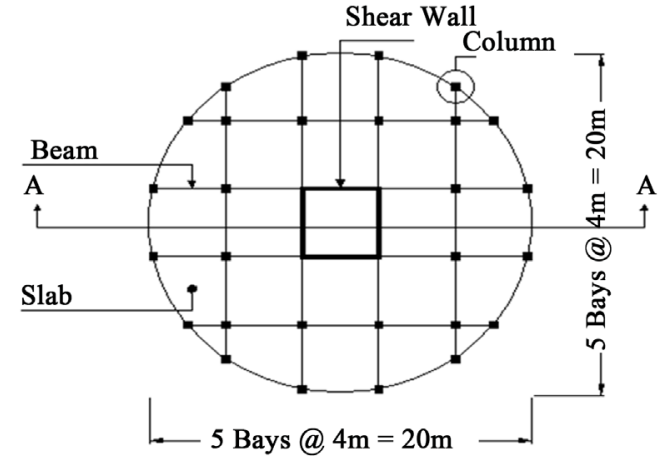

PLAN

Figure 9. Circular building floor plan and elevation.

Building shape, size, and height

STAAD PRO INPUT: Load combinations, earthquake zones, and soil profile

STAAD PRO OUTPUT: Building drift and reactions

STAAD FOUNDATION INPUT: Reactions as point loads, raft size, soil design parameters, and effective soil pressure

STAAD FOUNDATION OUTPUT:

Raft thickness, reinforcement, required size and settlement

End

Figure 10. Raft design process.

Table 3. Raft foundation design parameters.

\begin{tabular}{ccccccc}
\hline Soil Profile & $\begin{array}{c}Q_{s} \\
\mathrm{kN} / \mathrm{m}^{2}\end{array}$ & $\begin{array}{c}\gamma_{c} \\
\mathrm{kN} / \mathrm{m}^{3}\end{array}$ & $\begin{array}{c}f_{c}^{\prime} \\
\mathrm{MPa}\end{array}$ & $\begin{array}{c}\gamma_{\mathrm{s}} \\
\mathrm{kN} / \mathrm{m}^{3}\end{array}$ & $\begin{array}{c}f_{y} \\
\mathrm{MPa}\end{array}$ & $\begin{array}{c}\Delta_{\text {MAX }} \\
\mathrm{mm}\end{array}$ \\
\hline S1 & 3240 & & & & & \\
S2 & 1020 & & & & & \\
S3 & 440 & 25 & 30 & 18 & 420 & 50 \\
S4 & 245 & & & & & \\
S5 & 100 & & & &
\end{tabular}


software STAAD-Pro. These reactions were used as point loads for the design of the raft foundations. The design was performed using the finite element software STAAD-Foundation, as shown in Figure 11. The design of the raft foundation has to satisfy the requirements for one way shear, punching shear, bending moments, stresses, and settlements.

The results in Table 4 shows that the 7-story building raft foundation in zone 1 on soil profile 1 could be used in zone 5 on soil profile 5 with a small increase

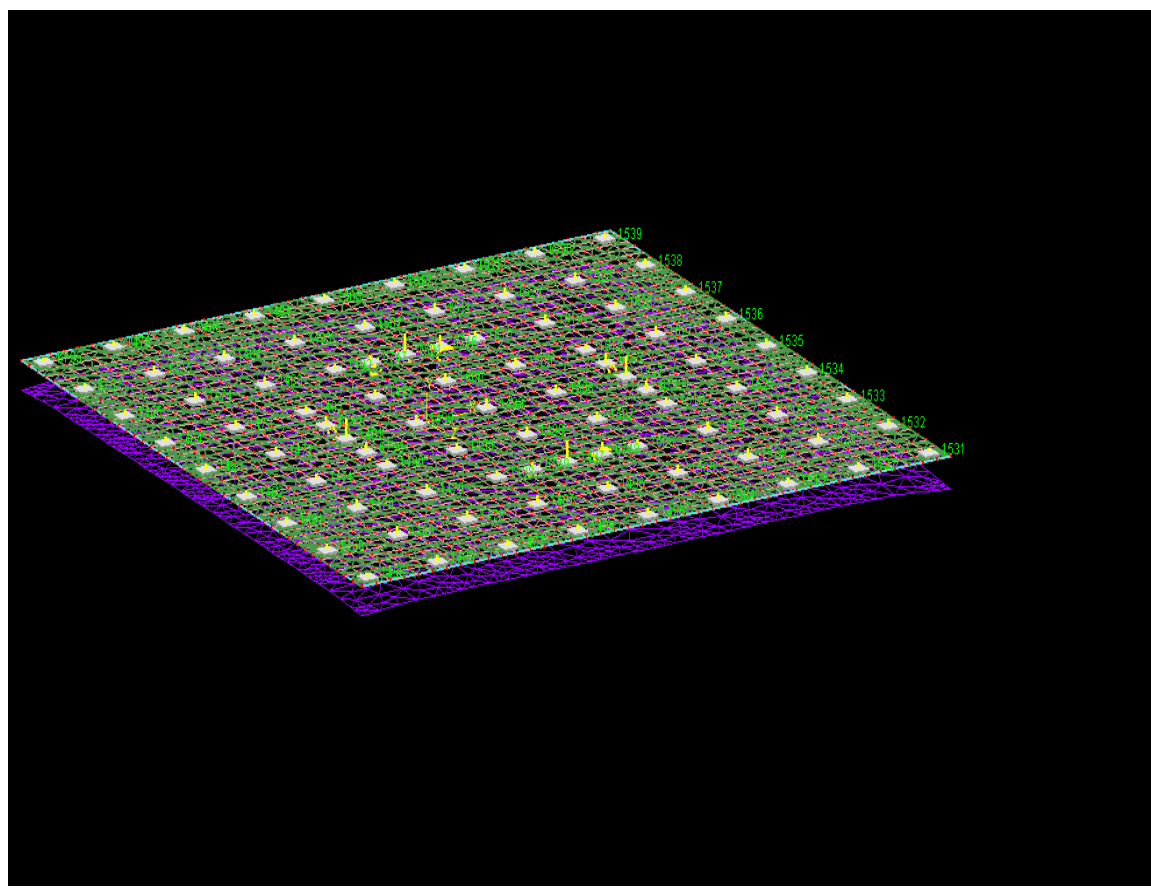

Figure 11. Raft foundation point loads and displacements.

Table 4. Raft dimensions and settlements.

\begin{tabular}{|c|c|c|c|c|c|c|c|c|c|}
\hline \multirow[b]{2}{*}{ Building } & \multirow{2}{*}{$\begin{array}{c}\text { Raft } \\
\text { Size } \\
\mathrm{m} \times \mathrm{m}\end{array}$} & \multicolumn{4}{|c|}{ Gravity Load } & \multicolumn{4}{|c|}{ Earthquake Load } \\
\hline & & S & $\begin{array}{c}\text { Total } \\
\text { Depth } \\
\text { m }\end{array}$ & $\begin{array}{l}\text { Total } \\
\text { AS } \\
\mathrm{mm}^{2}\end{array}$ & $\begin{array}{c}\Delta \\
\mathrm{mm}\end{array}$ & $\mathrm{Z} / \mathrm{S}$ & $\begin{array}{l}\text { Total } \\
\text { Depth } \\
\text { m }\end{array}$ & $\begin{array}{l}\text { Total } \\
\text { AS } \\
\mathrm{mm}^{2}\end{array}$ & $\begin{array}{c}\Delta \\
\mathrm{mm}\end{array}$ \\
\hline $\begin{array}{c}\text { Square } \\
30 \text { story } \\
120 \mathrm{~m} \text { Tall }\end{array}$ & $42 \times 42$ & 2 & 2.3 & 18209 & 4 & $\begin{array}{c}1 / 2 \\
5 / 2\end{array}$ & $\begin{array}{l}2.3 \\
2.4\end{array}$ & $\begin{array}{l}17,686 \\
19,781\end{array}$ & $\begin{array}{l}4 \\
5\end{array}$ \\
\hline $\begin{array}{c}\text { Tube } \\
18 \text { story } \\
72 \mathrm{~m} \text { Tall }\end{array}$ & $42 \times 42$ & 3 & 1.6 & 13048 & 4 & $\begin{array}{l}1 / 3 \\
5 / 3\end{array}$ & $\begin{array}{l}1.7 \\
1.9\end{array}$ & $\begin{array}{l}13,190 \\
15,769\end{array}$ & $\begin{array}{l}4 \\
5\end{array}$ \\
\hline $\begin{array}{c}\text { Rectangular } \\
12 \text { story } \\
48 \text { m Tall }\end{array}$ & $\begin{array}{l}22 \times 30 \\
39 \times 47 \\
46 \times 54\end{array}$ & $\begin{array}{c}1 \\
5 \\
\text { NA }\end{array}$ & $\begin{array}{c}0.8 \\
0.95 \\
\text { NA }\end{array}$ & $\begin{array}{c}6221 \\
7002 \\
\text { NA }\end{array}$ & $\begin{array}{l}2 \\
9\end{array}$ & $\begin{array}{l}1 / 1 \\
1 / 5 \\
5 / 5\end{array}$ & $\begin{array}{c}0.8 \\
0.95 \\
1.3\end{array}$ & $\begin{array}{c}6400 \\
9868 \\
19,753\end{array}$ & $\begin{array}{c}2 \\
10 \\
11\end{array}$ \\
\hline $\begin{array}{l}\text { Circular } \\
7 \text { story } \\
28 \mathrm{~m} \text { Tall }\end{array}$ & $\begin{array}{c}\text { Diameter } \\
21.6 \\
26.2 \\
28.8\end{array}$ & $\begin{array}{c}1 \\
5 \\
\text { NA }\end{array}$ & $\begin{array}{l}0.55 \\
0.55 \\
\text { NA }\end{array}$ & $\begin{array}{c}5003 \\
5020 \\
\text { NA }\end{array}$ & $\begin{array}{l}1 \\
6\end{array}$ & $\begin{array}{l}1 / 1 \\
1 / 5 \\
5 / 5\end{array}$ & $\begin{array}{l}0.55 \\
0.65 \\
0.85\end{array}$ & $\begin{array}{c}5039 \\
7149 \\
13,123\end{array}$ & $\begin{array}{l}1 \\
7 \\
8\end{array}$ \\
\hline
\end{tabular}


in size to satisfy the allowable soil pressure. The raft foundation for the 12-story building could be used in zone 5 on soil profile 5 but with a large increase in zone 1 raft size on soil profile 1 . For the 18-story building, the raft foundations on soil profiles 1, 2 and 3 are the only ones that satisfy the allowable soil pressure in all seismic zones. For the 30 -story building, the raft foundations on soil profiles 1 and 2 are the only ones that satisfy the allowable soil pressure in all zones. All raft foundation depths range between $0.55 \mathrm{~m}$ to $2.4 \mathrm{~m}$ to satisfy the raft shear and bending requirements. The required steel reinforcement area for all building raft foundations is in most cases equal to the minimum value set by $\mathrm{ACI}$ code. The raft foundation settlement is acceptable since it is less than $50 \mathrm{~mm}$ (12). Overall, the square building has less displacement and settlement than the circular one. On the other hand, the circular building has less displacement and less settlement than the tubular one.

\section{Conclusions}

Several reinforced concrete buildings with various configurations, heights, earthquake zones, and soil profiles have been analyzed and designed using the 3D finite element software STAAD-PRO as per ACI code and drift requirements. On the other hand, the raft foundations were analyzed and designed using the $3 \mathrm{D}$ finite element software STAAD-Foundation to determine the required raft size, depth, steel area, and settlement.

The reliability index $\beta$, which was developed to assess the reliability of the raft foundation in earthquake zones, was found to be larger than 2 indicating an acceptable and economical raft foundation sizes, depths, and steel areas.

The analysis and design results show that raft foundations could be used for low-rise buildings in earthquake zones on all soil profiles. They could also be used for buildings with heights ranging between 30 meters to 50 meters on soil profile 5, but with a large size increase. Moreover, raft foundations could be constructed on soil profile 1 to 3 for building heights between 50 meters to 70 meters in all in earthquake zones. They could also be constructed on soil profiles 1 and 2 for building heights between 70 meters and 120 meters in all earthquake zones. The raft settlements were acceptable for all buildings of the study. The square building had less roof displacement and settlement then had the circular one. On the other hand, the circular building had less roof displacement and settlement than did the tube one. In all cases, an efficient, reliable, and economical preliminary design for raft foundations could be achieved in all earthquake zones provided that it falls within the study recommendations and guide lines.

\section{References}

[1] Khobragade, N.D. and Nikhade, A. (2016) Effects of Seismic Forces on Multi-Storey Building for Different Zones \& Soil Condition. International Journal for Technological Research in Engineering, 3, 2368-2371.

[2] Naidu, M. and Bhole, S.D. (2016) Seismic Analysis of Multi-Storied Building and Critical Study of Its Foundation. Int. J. of Science Tech. \& Engineering, 2, 749-755. 
[3] Naidu, M. and Bhole, S.D. (2011) Influence of Structural and Soil Parameters on Mat Deflection. International Journal of Civil and Structural Engineering, 2, 1-10.

[4] Dalia, A.S. and Soubra, A.H. (2008) Reliability-Based Analysis of Strip Footing Using Response Surface Methodology. Geomechanics, ASCE, 8, 134-143.

[5] International Conference of Building Officials (1997) Uniform Building Code. Whittier, CA.

[6] International Code Council (2009) International Building Code. Illinois.

[7] Al-Ansari, M.S. (2009) Drift Optimization of High-Rise Buildings in Earthquake Zones. Journal of Tall and Special Building, 2, 291-307.

[8] American Concrete Institute (ACI) (2008) Building Code and Commentary. Detroit.

[9] Nowak, A.S. and Collins, K.R. (2013) Reliability of Structures. CRC Press, New York.

[10] Bentley System Inc. (2009) STAAD PRO V8i. Three Dimensional Static and Dynamic Finite Element Analysis and Design of Structures. Yorba Linda, CA.

[11] Bowles, J.E. (1988) Foundation Analysis and Design. McGraw Hill, New York.

[12] Bentley System Inc. (2009) STAAD FOUNDATION V8i. Three Dimensional Static and Dynamic Finite Element Analysis and Design of Structures. Yorba Linda, CA. 